\title{
KINERJA OPERASIONAL PELABUHAN PERIKANAN NUSANTARA TUAL
}

\section{(OPERATIONAL PERFORMANCE OF TUAL ARCHIPELAGIC FISHING PORT)}

\author{
Yuliana Anastasia Ngamel ${ }^{1,2}$, Ernani Lubis ${ }^{3}$, Anwar Bey Pane ${ }^{3}$, dan Iin Solihin ${ }^{3}$ \\ ${ }^{1}$ Corresponding author \\ ${ }^{2}$ Politeknik Perikanan Negeri Tual \\ ${ }^{3}$ Departemen Pemanfaatan Sumberdaya Perikanan \\ Fakultas Perikanan dan Ilmu Kelautan, Institut Pertanian Bogor \\ E-mail: ngamelrahaded@yahoo.com
}

\begin{abstract}
Tual Archipelagic Fishing Port (PPN Tual) is located near the Banda Sea (WPP-NRI 714) and the Arafura Sea (WPP-NRI 718) which is also an area of fishing ground. The potential of fishing ground, it should be operational performance in PPN Tual can well and growing. In fact PPN Tual has not been operating optimally based on the standards of the fishing port type B. The purpose of the research are to get the value of performance and strategy to increase of operational performance PPN Tual. The research was conducted using the case study method of operational performance in PPN Tual that analyzed using is scoring method. The results showed that the value operational performance of PPN Tual is $21.61 \%$ and it was said that the PPN Tual operational performance is bad.
\end{abstract}

Keywords: Performance operational, fishing port, Tual Archipelagic Fishing Port (PPN Tual)

\begin{abstract}
ABSTRAK
Pelabuhan Perikanan Nusantara Tual (PPN Tual) terletak dekat dengan Laut Banda (WPP-NRI 714) dan Laut Arafura (WPP-NRI 718) yang juga merupakan daerah penangkapannya. Dengan potensi daerah penangkapannya, seharusnya kinerja operasional di PPN Tual dapat berjalan dengan baik dan berkembang. Kenyataannya PPN Tual belum beroperasi secara optimal berdasarkan standar pelabuhan perikanan tipe B. Penelitian ini bertujuan untuk mendapatkan Nilai Kinerja operasional PPN Tual. Penelitian dilaksanakan menggunakan metode studi kasus terhadap kinerja operasional PPN Tual yang dianalisis dengan menggunakan scoring method. Hasil penelitian menunjukkan bahwa Nilai Kinerja operasional PPN Tual adalah $21,61 \%$ dan dikatakan buruk.
\end{abstract}

Kata kunci: Kinerja operasional, pelabuhan perikanan, Pelabuhan Perikanan Nusantara Tual (PPN Tual)

\section{PENDAhuluan}

Salah satu pelabuhan perikanan yang terdapat di Provinsi Maluku adalah Pelabuhan Perikanan Nusantara Tual (PPN Tual) yang terletak di Kota Tual. Dalam pengelolaannya PPN Tual berada di bawah pemerintah pusat yaitu Unit Pelaksana Teknis (UPT) Direktorat Jenderal Perikanan Tangkap yang berada di Tual. Pelabuhan Perikanan Nusantara Tual terletak dekat dengan Laut Banda dan Laut Arafura yang juga merupakan daerah penangkapannya. Laut Banda dan Laut Arafura merupakan wilayah perairan yang masuk dalam Wilayah Pengelolaan Perikanan Negara Republik Indonesia (WPP-NRI) 714 dan 718. Menurut Keputusan Menteri Kelautan dan Perikanan Republik Indonesia Nomor 45 Tahun 2011 tentang Estimasi Potensi
Sumber Daya Ikan di Wilayah Pengelolaan Perikanan Negara Republik Indonesia bahwa estimasi potensi sumberdaya ikan di WPP-NRI 714 adalah 278.000 ton/tahun sedangkan di WPPNRI 718 adalah 855.500 ton/tahun. Wilayah Pengelolaan Perikanan Negara Republik Indonesia (WPP-NRI) 714 memiliki kelompok sumberdaya ikan dengan status tingkat ekploitasi overexploited untuk ikan tuna mata besar, fully-exploited untuk ikan demersal, pelagis kecil dan tuna madidihang, moderate to fully exploited untuk ikan Decapterus macarellus (layang biru) dan Decapterus macrosoma (layang deles) dan moderate untuk ikan cakalang dan cumi-cumi. Wilayah Pengelolaan Perikanan Negara Republik Indonesia (WPP-NRI) 718 memiliki kelompok sumberdaya ikan dengan status tingkat ekploitasi over- 
exploited untuk ikan demersal, fullyexploited untuk udang dan ikan lidah, dan moderate untuk ikan pelagis kecil.

Berdasarkan potensi yang dimiliki daerah penangkapannya, maka seharusnya kinerja operasional di PPN Tual dapat berjalan dengan baik dan berkembang. Namun kenyataan yang ada bahwa PPN Tual sebagai Pelabuhan Perikanan (PP) dengan tipe Nusantara, sampai saat ini masih belum sepenuhnya menunjukkan kinerjanya sebagai PPN sebagaimana dalam Peraturan Menteri Kelautan dan Perikanan Republik Indonesia Nomor 08 Tahun 2012 tentang Kepelabuhanan Perikanan. Pelabuhan Perikanan Nusantara Tual belum mampu menghasilkan jumlah kunjungan kapal sesuai standar pelabuhan perikanan tipe B yang diatur dalam Peraturan Menteri Kelautan dan Perikanan Republik Indonesia Nomor 08 Tahun 2012 yaitu 27.375 unit/tahun. Menurut data yang diperoleh dari PPN Tual, bahwa frekuensi jumlah kunjungan kapal tahun 2008, 2009, dan 2010. Semakin menurun yaitu sebesar 78, 73, dan 37 unit kali. Namun tahun 2011 meningkat menjadi 140 unit kali. Penyebab dari meningkatnya jumlah kunjungan kapal pada tahun 2011 ini adalah diduga dengan adanya kapalkapal penangkap ikan yang beroperasi di perairan dekat PPN Tual yang belum pernah berkunjung di PPN Tual. Pada saat itu mengalami kesulitan biaya operasional sehingga mereka memilih untuk berlabuh di PPN Tual dan tidak melakukan aktifitas penangkapan lagi. Tahun 2012 kunjungan kapal kembali mengalami penurunan menjadi 29 unit kali. Menurunnya jumlah kunjungan kapal di PPN Tual ini diduga kapal penangkap ikan awalnya mendaratkan hasil tangkapan di PPN Tual akan tetapi tidak melakukan pendaratan hasil tangkapan di PPN Tual. Hasil tangkapan yang didaratkan di PPN Tual juga masih dibawah standar pelabuhan perikanan tipe B yaitu 10.950 ton/tahun. Hal tersebut tidak sebanding dengan potensi sumberdaya perikanan di daerah penangkapannya. Rendahnya jumlah kunjungan kapal yang terjadi di PPN Tual mengakibatkan menurunnya produksi hasil tangkapan dan berpengaruh terhadap kinerjanya. Parameter produksi merupakan salah satu parameter yang mendukung besarnya Nilai Kinerja operasional PPN Tual. Semakin banyak pro- duksi ikan yang didaratkan maka semakin ramai pula kegiatan yang terjadi di pelabuhan perikanan tersebut, sehingga kinerja operasionalnya akan meningkat pula.

Oleh karena itu diperlukan adanya penelitian untuk menilai kinerja operasional PPN Tual dalam menjalankan fungsinya sesuai tujuan awal pembangunannya. Salah satu untuk meningkatkan kinerja tersebut yaitu melakukan usaha meningkatkan kembali produksi hasil tangkapan dengan memanfaatkan potensi sumberdaya ikan di WPP-NRI 714 dan 718. Penelitian ini bertujuan untuk mendapatkan nilai kinerja PPN Tual. Adapun manfaat dari penelitian ini adalah memberikan pertimbangan bagi pengelola PPN Tual terhadap strategi peningkatan kinerja operasional dan sebagai bahan informasi dasar bagi akademisi untuk penelitian lanjutan terhadap pengembangan PPN Tual.

\section{METODOLOGI}

Penelitian dilakukan pada bulan Maret sampai April 2013, bertempat di Pelabuhan Perikanan Nusantara Tual (PPN Tual), Provinsi Maluku. Penelitian dilaksanakan menggunakan metode studi kasus. Pada penelitian ini ingin diketahui secara khusus tentang kondisi aktual dari fasilitas yang digunakan beserta aktivitas yang terjadi di PPN Tual dan kinerja operasional di PPN Tual. Data yang digunakan untuk keperluan penelitian ini mencakup data utama dan tambahan. Data utama yang dikumpulkan dibedakan menjadi data primer dan data sekunder. Pengambilan data primer dilakukan melalui pengamatan langsung di lapangan, wawancara kepada responden dan pengisian kuesioner. Responden dipilih menggunakan metode purposive sampling. Data sekunder diperoleh dari instansi-instansi terkait, studi pustaka dan dari berbagai sumber data yang diperoleh melalui internet. Data primer terdiri dari kegiatan operasional PPN Tual dan fasilitas-fasilitas yang digunakan untuk melakukan aktivitas di PPN Tual, sedangkan data sekunder yang dikumpulkan yaitu data produksi hasil tangkapan yang didaratkan (ton/tahun), data jumlah kunjungan kapal, penyediaan perbekalan BBM dan air bersih (ton/ tahun) serta jenis-jenis fasilitas yang 
terdapat di PPN Tual. Data tambahan hanya terdiri dari data sekunder yang terdiri dari profil PPN Tual yaitu mengenai tugas dan fungsi, struktur organisasi dan fasilitas di PPN Tual.

Metode analisis data yang digunakan adalah metode pembobotan atau scoring method. Pada penelitian ini ada beberapa istilah yang dibatasi pengertiannya agar tidak keliru dalam pemahamannya yaitu pengertian kinerja operasional dan kunjungan kapal. Pengertian kinerja operasional pelabuhan perikanan dalam penelitian ini adalah hasil kerja secara kualitas dan kuantitas yang dicapai pelabuhan perikanan dalam melaksanakan tugas sesuai visi dan misinya yang mengacu pada Keputusan Direktur Jenderal Perikanan Tangkap Nomor 432/ DPT3/OT.220.D3/I/2008 tentang Pedoman Evaluasi Kinerja Unit Pelaksana Teknis Pelabuhan Perikanan. Kunjungan kapal yang dimaksud dalam penelitian ini adalah kunjungan kapal yang dilakukan di pelabuhan perikanan untuk melakukan kegiatan mendaratkan hasil tangkapan, mengisi perbekalan melaut, mengurus dokumen persetujuan berlayar, mengadakan perbaikan dan pemeliharaan kapal dan menunggu waktu melaut kembali.

Semua parameter yang digunakan diasumsikan mempunyai tingkat kepentingan yang berbeda sehingga menyebabkan bobot dari masing-masing parameter dan variabel juga berbeda. Parameter yang diukur untuk menilai kinerja operasional PPN Tual diketahui dengan mencari informasi mengenai tujuan pembangunan PPN Tual. Parameter yang digunakan tersebut dikategorikan menjadi dua kategori yaitu parameter berdasarkan Keputusan Direktur Jenderal Perikanan Tangkap Nomor 432/DPT3/ OT.220.D3/I/2008 yang disingkat parameter DJPT dan parameter non-DJPT yaitu parameter pemasaran dan kepuasan nelayan. Parameter DJPT terdiri dari produksi hasil tangkapan, kunjungan kapal dan penyediaan perbekalan melaut dengan variabelnya adalah penyediaan perbekalan BBM dan air bersih, sedangkan parameter non-DJPT terdiri dari pemasaran dan kepuasan nelayan. Parameter pemasaran terdiri dari variabel-variabel pemasaran lokal dan pemasaran antar daerah. Parameter kepuasan nelayan meliputi variabelvariabel kepuasan terhadap penyediaan dan pelayanan fasilitas perbekalan, kepuasan terhadap penyediaan dan pelayanan fasilitas perbaikan, kepuasan terhadap penyediaan dan pelayanan fasilitas pendaratan dan pembongkaran serta kepuasan terhadap penyediaan dan pelayanan fasilitas pemasaran.

\section{Nilai kinerja operasional untuk para- meter DJPT}

Penilaian kinerja untuk parameter

DJPT dilakukan dengan tahapan sebagai berikut:

1) Penentuan bobot

Pada tahapan ini setiap parameter dan variabel diberikan bobot sesuai dengan tingkat kepentingannya. Pemberian bobot dilakukan oleh peneliti berdasarkan pengalaman peneliti dan setelah melakukan wawancara dengan ahli-ahli pelabuhan dan orang-orang yang mengerti betul tentang situasi yang terjadi di PPN Tual (Tabel 1).

2) Penentuan kriteria pengambilan keputusan

Peneliti membuat kriteria pengambilan keputusan kinerja operasional suatu pelabuhan perikanan, yang dapat dilihat pada Tabel 2. Pencapaian nilai $100 \%$ dari hasil penilaian kinerja operasional ini, diartikan bahwa pengelola pelabuhan perikanan yang dinilai sudah menghasilkan kinerja yang telah sesuai dengan Keputusan Direktur Jenderal Perikanan Tangkap Nomor 432/DPT3/ OT.220.D3/I/2008.

3) Penentuan Nilai Kinerja

Perhitungan Nilai Kinerja diawali dengan menentukan Nilai Keberhasilan. Nilai Keberhasilan diperoleh dengan cara membandingkan nilai realisasi yang terjadi di PPN Tual tahun 2012 dengan nilai standar pembanding menurut Keputusan Direktur Jenderal Perikanan Tangkap Nomor 432/DPT3/OT.220.D3/I/2008 tentang Pedoman Evaluasi Kinerja Unit Pelaksana Teknis Pelabuhan Perikanan (Tabel 3). Penentuan nilai keberhasilan untuk parameter DJPT dapat dilihat pada Tabel 4. Setelah Nilai Keberhasilan diperoleh, maka nilai tersebut dikalikan dengan bobot untuk masing-masing parameter dan variabel yang telah ditentukan. Selanjutnya hasil perkalian tersebut dinamakan Nilai Kinerja $\left(K_{j}\right)$ dan dapat dilihat pada Tabel 5 . 
Tabel 1. Tabel bobot parameter dan variabel data DJPT

\begin{tabular}{|c|c|c|c|}
\hline Parameter (i) & $\begin{array}{c}\text { Bobot Parameter } \\
\left(\mathrm{BP}_{\mathrm{i}}\right)\end{array}$ & Variabel (j) & $\begin{array}{c}\text { Bobot Variabel } \\
\left(\mathrm{BV}_{\mathrm{j}}\right)\end{array}$ \\
\hline $\begin{array}{l}\text { 1. Produksi hasil } \\
\text { tangkapan }\end{array}$ & 35 & $\begin{array}{l}\text { 1) Produksi hasil } \\
\text { tangkapan per tahun } \\
\text { (ton/tahun) }\end{array}$ & 100 \\
\hline $\begin{array}{l}\text { 2. Kunjungan } \\
\text { kapal }\end{array}$ & 35 & $\begin{array}{l}\text { 1) Frekuensi kunjungan } \\
\text { kapal per tahun (unit } \\
\text { kali/tahun) }\end{array}$ & 100 \\
\hline \multirow{2}{*}{$\begin{array}{l}\text { 3. Penyediaan } \\
\text { perbekalan } \\
\text { melaut }\end{array}$} & 30 & $\begin{array}{l}\text { 1) Penyediaan BBM } \\
\text { (ton/tahun) }\end{array}$ & 50 \\
\hline & & $\begin{array}{l}\text { 2) Penyediaan air bersih } \\
\text { (ton/tahun) }\end{array}$ & 50 \\
\hline
\end{tabular}

Keterangan:

$\mathrm{i} \quad=1,2, \ldots \mathrm{n}$; parameter $(\mathrm{n}=3)$; produksi hasil tangkapan, kunjungan kapal dan penyediaan perbekalan melaut

$\mathrm{j}=1,2, \ldots \mathrm{m} ;$ variabel $(\mathrm{m}=4)$;

Tabel 2. Tabel kriteria pengambilan keputusan kinerja operasional pelabuhan perikanan untuk parameter DJPT atau non-DJPT

\begin{tabular}{ll}
\hline Nilai Kinerja & Pengambilan Keputusan (Kriteria Kinerja) \\
\hline $80 \% \leq \mathrm{K} \leq 100 \%$ & Kinerja pelabuhan perikanan sangat baik \\
$60 \% \leq \mathrm{K}<80 \%$ & Kinerja pelabuhan perikanan baik \\
$40 \% \leq \mathrm{K}<60 \%$ & Kinerja pelabuhan perikanan cukup baik \\
$20 \% \leq \mathrm{K}<40 \%$ & Kinerja pelabuhan perikanan buruk \\
$0 \% \leq \mathrm{K}<20 \%$ & Kinerja pelabuhan perikanan sangat buruk \\
\hline
\end{tabular}

Tabel 3. Tabel nilai standar pembanding untuk parameter DJPT

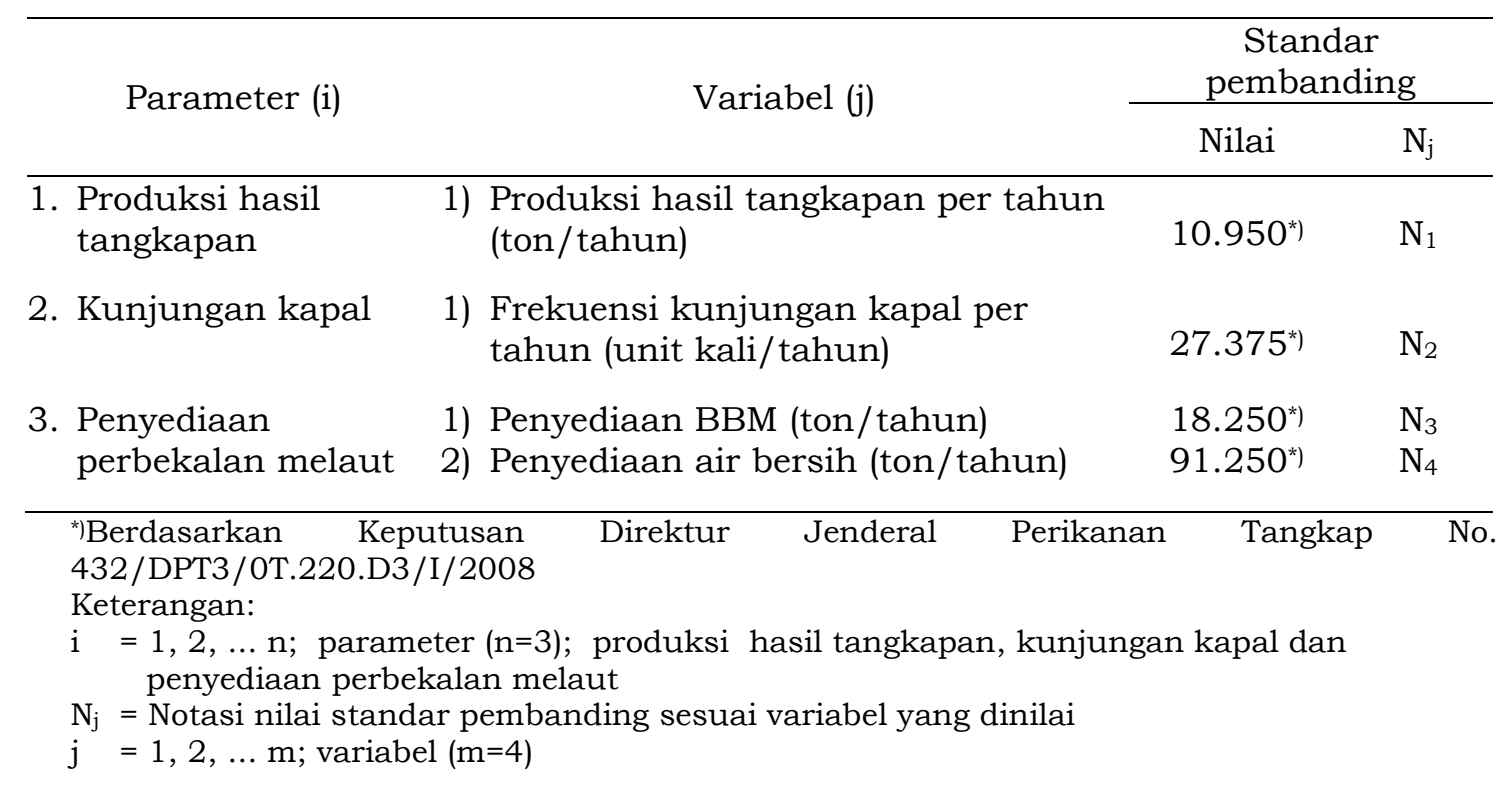


Tabel 4. Tabel perhitungan Nilai Keberhasilan untuk parameter DJPT

Parameter (i)

Variabel (j)
Nilai

Keberhasilan

$\left(A_{j} ; \%\right)$
1. Produksi hasil tangkapan

2. Kunjungan kapal

3. Penyediaan perbekalan melaut
1) Produksi hasil tangkapan per tahun (ton/tahun)

$$
A_{1}=\frac{X_{1}}{N_{1}} \times 100 \%
$$

1) Frekuensi kunjungan kapal per tahun (unit kali/tahun)

$$
A_{2}=\frac{X_{2}}{N_{2}} \times 100 \%
$$$$
A_{3}=\frac{X_{3}}{N_{3}} \times 100 \%
$$

1) Penyediaan BBM (ton/tahun)

$$
A_{4}=\frac{X_{4}}{N_{4}} \times 100 \%
$$

\footnotetext{
Keterangan:

$\mathrm{X}_{\mathrm{j}}=$ Nilai realisasi sesuai variabel ke-j di PPN TUAL tahun 2012

$\mathrm{X}_{1}=$ Nilai realisasi jumlah produksi hasil tangkapan (ton/tahun)

$\mathrm{X}_{2}=$ Nilai realisasi jumlah kunjungan kapal (unit kali/tahun)

$\mathrm{X}_{3}=$ Nilai realisasi jumlah penyediaan BBM (ton/tahun)

$\mathrm{X}_{4}=$ Nilai realisasi jumlah penyediaan air bersih (ton/tahun)

$\mathrm{A}_{\mathrm{j}}=$ Nilai keberhasilan sesuai variabel ke-j

$\mathrm{S}_{\mathrm{j}}=$ Skor kinerja sesuai variabel ke- $\mathrm{j}$

\begin{tabular}{|c|c|c|c|c|c|c|}
\hline Parameter (i) & & Variabel (j) & $\begin{array}{c}\text { Nilai } \\
\text { Keberhasilan } \\
\left(\mathrm{A}_{\mathrm{j}}\right)\end{array}$ & $\begin{array}{c}\text { Bobot } \\
\text { Parameter } \\
\left(\mathrm{BP}_{\mathrm{i}}\right)\end{array}$ & $\begin{array}{c}\text { Bobot } \\
\text { Variabel } \\
\left(\mathrm{BV}_{\mathrm{j}}\right)\end{array}$ & Nilai Kinerja $\left(K_{j}\right)$ \\
\hline $\begin{array}{l}\text { 1. Produksi hasil } \\
\text { tangkapan }\end{array}$ & 1) & $\begin{array}{l}\text { Produksi per } \\
\text { tahun } \\
\text { (ton/tahun) }\end{array}$ & $\mathrm{A}_{1}$ & $\mathrm{BP}_{1}$ & $\mathrm{BV}_{1}$ & $\begin{array}{c}K_{1}=A_{1} \times B P_{1} x \\
B V_{1}\end{array}$ \\
\hline $\begin{array}{l}\text { 2. Kunjungan } \\
\text { kapal }\end{array}$ & 1) & $\begin{array}{l}\text { Frekuensi } \\
\text { kunjungan } \\
\text { kapal per } \\
\text { tahun (unit } \\
\text { kali/tahun) }\end{array}$ & $\mathrm{A}_{2}$ & $\mathrm{BP}_{2}$ & $\mathrm{BV}_{2}$ & $\begin{array}{c}K_{2}=A_{2} \times B P_{2} \times \\
B V_{2}\end{array}$ \\
\hline \multirow[t]{3}{*}{$\begin{array}{l}\text { 3. Penyediaan } \\
\text { perbekalan } \\
\text { melaut }\end{array}$} & 1) & $\begin{array}{l}\text { Penyediaan } \\
\text { BBM } \\
\text { (ton/tahun) }\end{array}$ & $\mathrm{A}_{3}$ & \multirow[t]{2}{*}{$\mathrm{BP}_{3}$} & $\mathrm{BV}_{3}$ & $\begin{array}{c}K_{3}=A_{3} x B P_{3} x \\
B V_{3}\end{array}$ \\
\hline & 2) & $\begin{array}{l}\text { Penyediaan } \\
\text { air bersih } \\
\text { (ton/tahun) }\end{array}$ & $\mathrm{A}_{4}$ & & $\mathrm{BV}_{4}$ & $\begin{array}{c}K_{4}=A_{4} \times B P_{3} x \\
B V_{4}\end{array}$ \\
\hline & & \multicolumn{3}{|c|}{ Nilai Kinerja parameter DJPT (K } & \multicolumn{2}{|c|}{$=\frac{K_{1}+K_{2}+K_{3}+K_{4}}{j}$} \\
\hline
\end{tabular}

$\mathrm{j}=1,2, \ldots . \mathrm{m}$; variabel $(\mathrm{m}=4)$;
}

Tabel 5. Tabel penentuan Nilai Kinerja untuk parameter DJPT 
Nilai Kinerja parameter DJPT (K $\left.\mathrm{K}_{\mathrm{DJPT}}\right)$ diperoleh dari rata-rata nilai kinerja dari variabel-variabel produksi hasil tangkapan, kunjungan kapal dan penyediaan perbekalan melaut. Berdasarkan hasil nilai $\mathrm{K}_{\mathrm{DJPT}}$ yang diperoleh kemudian dilakukan pengambilan keputusan mengenai kinerja operasional PPN TUAL untuk parameter DJPT, yang membandingkannya dengan kriteria kinerja di Tabel 2.

\section{Nilai Kinerja operasional untuk parameter non-DJPT}

Penilaian kinerja untuk parameter non-DJPT dilakukan dengan tahapan sebagai berikut :

1) Penentuan bobot

Pada tahapan ini setiap parameter dan variabel diberikan bobot sesuai dengan tingkat kepentingannya oleh peneliti berdasarkan pengalaman peneliti dan setelah melakukan wawancara dengan ahli-ahli pelabuhan dan orangorang yang mengerti betul tentang situasi yang terjadi di PPN Tual. Penentuan bobot untuk parameter non-DJPT ini dipisahkan antara parameter pemasaran dan kepuasan nelayan dengan asumsi bahwa kedua parameter ini mempunyai perbedaan dalam perhitungan sehingga penentuan bobotnya juga dipisahkan. Adapun bobot untuk parameter pemasaran dapat dilihat pada Tabel 6 sedangkan bobot untuk parameter kepuasan nelayan dapat dilihat pada Tabel 7 .

2) Penentuan kriteria pengambilan keputusan

Peneliti juga membuat kriteria pengambilan keputusan kinerja operasional pelabuhan perikanan untuk parameter non-DJPT, sama seperti pada parameter DJPT (Tabel 2). Pencapaian $100 \%$ kepuasan nelayan berarti nelayan sangat puas terhadap kinerja operasional pelabuhan perikanan untuk parameter non-DJPT.

3) Penentuan Nilai Kinerja

Perhitungan Nilai Kinerja untuk parameter non-DJPT dipisahkan antara parameter pemasaran dan parameter kepuasan nelayan.

- Parameter pemasaran

Penentuan Nilai Kinerja diawali dengan menentukan Nilai Maksimum hasil perkalian antara Bobot Variabel dengan Skor Maksimum. Pada parameter pemasaran, peneliti menggunakan Skor mak- simum sebagai acuan antar pembanding berdasarkan jumlah pemasaran hasil tangkapan Pelabuhan Perikanan Nusantara (PPN) Brondong tahun 2012; dengan asumsi jumlah pemasaran hasil tangkapan PPN Brondong merupakan jumlah pemasaran terbaik di Indonesia untuk kelas Pelabuhan Perikanan Nusantara.

Berdasarkan hasil komunikasi pribadi dengan staf Direktorat Jenderal Perikanan Tangkap Kementerian Kelautan dan Perikanan, dinyatakan bahwa PPN Brondong merupakan salah satu PPN yang dinilai terbaik di Indonesia selain PPN Palabuhanratu, PPN Ternate dan PPN Pekalongan. Data lengkap tentang pemasaran untuk keempat PPN ini yang dapat diperoleh peneliti hanya data dari PPN Brondong. Dengan demikian Skor Maksimum yang digunakan untuk pemasaran lokal adalah $1.313,3$ ton yang merupakan estimasi jumlah pemasaran lokal di PPN Brondong sedangkan untuk pemasaran antar daerah adalah 24.952,7 ton yang merupakan estimasi jumlah pemasaran antar daerah di PPN Brondong (Tabel 8). Parameter ini untuk pemasaran luar negeri tidak digunakan, dalam Peraturan Menteri Kelautan dan Perikanan Republik Indonesia Nomor 08 Tahun 2012 tentang Kepelabuhanan Perikanan, tidak mewajibkan untuk sebuah PPN melakukan pemasaran luar negeri, selain itu juga untuk tahun 2012 pemasaran di PPN Tual tidak ada untuk tujuan luar negeri.

Nilai Bobot Skor Maksimum ini digunakan sebagai pembanding untuk memperoleh Nilai Keberhasilan parameter pemasaran, yaitu perbandingan antara jumlah pemasaran di PPN Tual terhadap Nilai Bobot Skor Maksimum. Nilai Kinerja $\left(\mathrm{K}_{1}\right)$ setiap variabel pemasaran, merupakan Nilai Keberhasilan. Nilai Kinerja $\left(\mathrm{K}_{5}\right)$ merupakan nilai rata-rata dari Nilai Keberhasilan suatu variabel pemasaran. Perhitungan nilai kinerja parameter pemasaran dapat dilihat pada Tabel 9. Pengambilan keputusan Nilai Kinerja parameter berdasarkan pada pemasaran pelabuhan perikanan dilakukan dengan cara membandingkan nilai $\mathrm{K}_{5}$ terhadap kriteria pengambilan keputusan kinerja pemasaran pelabuhan perikanan di Tabel 10. 
Tabel 6. Tabel bobot Parameter dan Bobot Variabel untuk parameter pemasaran

\begin{tabular}{|c|c|c|c|c|}
\hline Parameter (k) & & Variabel (1) & $\begin{array}{c}\text { Bobot Parameter } \\
\left(\mathrm{BP}_{\mathrm{k}}\right)\end{array}$ & $\begin{array}{c}\text { Bobot Variabel } \\
\left(\mathrm{BV}_{\mathrm{l}}\right)\end{array}$ \\
\hline \multirow{2}{*}{ Pemasaran } & 1) & $\begin{array}{l}\text { Pemasaran lokal } \\
\text { (ton/tahun) }\end{array}$ & \multirow{2}{*}{100} & 40 \\
\hline & 2) & $\begin{array}{l}\text { Pemasaran antar } \\
\text { daerah (ton/tahun) }\end{array}$ & & 60 \\
\hline $\begin{array}{l}\text { Keterangan : } \\
\mathrm{k}=\text { Banyak } \\
1 \quad=\text { Banyak }\end{array}$ & & $\begin{array}{l}\text { ter pemasaran; } \mathrm{k}=1 \\
\text { pemasaran; } 1=2\end{array}$ & & \\
\hline
\end{tabular}

Tabel 7. Tabel Bobot Parameter dan Bobot Variabel untuk parameter kepuasan nelayan

\begin{tabular}{cccc}
\hline $\begin{array}{c}\text { Parameter } \\
(\mathrm{m})\end{array}$ & $\begin{array}{c}\text { Bobot Parameter } \\
\left(\mathrm{BP}_{\mathrm{m}}\right)\end{array}$ & \multicolumn{1}{c}{ Variabel $(\mathrm{n})$} & $\begin{array}{c}\text { Bobot Variabel } \\
\left(\mathrm{BV}_{\mathrm{n}}\right)\end{array}$ \\
\hline & & 1) $\begin{array}{l}\text { Kepuasan nelayan terhadap } \\
\text { fasilitas perbekalan }\end{array}$ & 30 \\
& 2) $\begin{array}{l}\text { Kepuasan nelayan terhadap } \\
\text { fasilitas perbaikan }\end{array}$ & 15 \\
$\begin{array}{l}\text { Kepuasan } \\
\text { nelayan }\end{array}$ & 3) $\begin{array}{l}\text { Kepuasan nelayan terhadap } \\
\text { fasilitas pendaratan dan } \\
\text { pembongkaran }\end{array}$ & 35 \\
& 4) $\begin{array}{l}\text { Kepuasan nelayan terhadap } \\
\text { fasilitas pemasaran }\end{array}$ & 20 \\
\hline
\end{tabular}

Keterangan :

$\mathrm{m}=$ Banyak parameter kepuasan nelayan; $\mathrm{m}=1$

$\mathrm{n}$ = Banyak variabel kepuasan nelayan; $\mathrm{n}=4$

Tabel 8. Tabel perhitungan Nilai Bobot Skor Maksimum untuk parameter pemasaran

\begin{tabular}{|c|c|c|c|c|c|}
\hline $\begin{array}{c}\text { Parameter } \\
(\mathrm{k})\end{array}$ & & $\begin{array}{l}\text { Variabel } \\
\text { (1) }\end{array}$ & $\begin{array}{c}\text { Bobot } \\
\text { Variabel } \\
\left(\mathrm{BV}_{1}\right) \\
\end{array}$ & $\begin{array}{c}\text { Skor } \\
\text { Maksimum } \\
\left(\mathrm{SM}_{1}\right) \\
\end{array}$ & $\begin{array}{l}\text { Nilai Bobot Skor } \\
\text { Maksimum (NM) } \\
\left(\mathrm{BV}_{1} \times \mathrm{SM}_{1}\right)\end{array}$ \\
\hline \multirow[t]{2}{*}{ 1. Pemasaran } & 1) & $\begin{array}{l}\text { Lokal } \\
\text { (ton/tahun) }\end{array}$ & 60 & $1.313,3$ & $\begin{aligned} \mathrm{NM}_{\mathrm{lok}} & =\mathrm{BV}_{\mathrm{lok}} \times \mathrm{SM}_{\mathrm{lok}} \\
& =52.532\end{aligned}$ \\
\hline & 2) & $\begin{array}{l}\text { Antar daerah } \\
\text { (ton/tahun) }\end{array}$ & 40 & $24.952,7$ & $\begin{aligned} \mathrm{NM}_{\text {anda }} & =\mathrm{BV}_{\text {anda }} \times \mathrm{SM}_{\text {and }} \\
& =1.497 .162\end{aligned}$ \\
\hline
\end{tabular}

Keterangan :

$\mathrm{k} \quad=$ Banyak parameter pemasaran; $\mathrm{k}=1$

1 = Banyak variabel pemasaran; $1=2$

- Parameter kepuasan nelayan

Sebelum menentukan Nilai Kinerja maka perlu diketahui terlebih dahulu Skor Maksimum untuk parameter kepuasan nelayan. Skor Maksimum untuk parameter kepuasan nelayan diperoleh dari skala maksimum pada kuesioner yang diberikan yaitu 5. Skala untuk pendapat responden dapat dilihat pada Tabel 11 .

Pengisian kuesioner oleh responden nelayan bertujuan untuk mengetahui tingkat kepuasan responden nelayan yang di interview terhadap penyediaan dan pelayanan fasilitas perbekalan, pemeliharaan dan perbaikan, pendaratan dan pembongkaran serta pemasaran. Skor jawaban responden menggunakan skala tingkat 5 dimana nilai 1 hingga 5 menunjukkan pengertian yang berbedabeda, mulai dari tidak puas hingga sangat puas. 
Tabel 9. Tabel perhitungan Nilai Kinerja parameter pemasaran

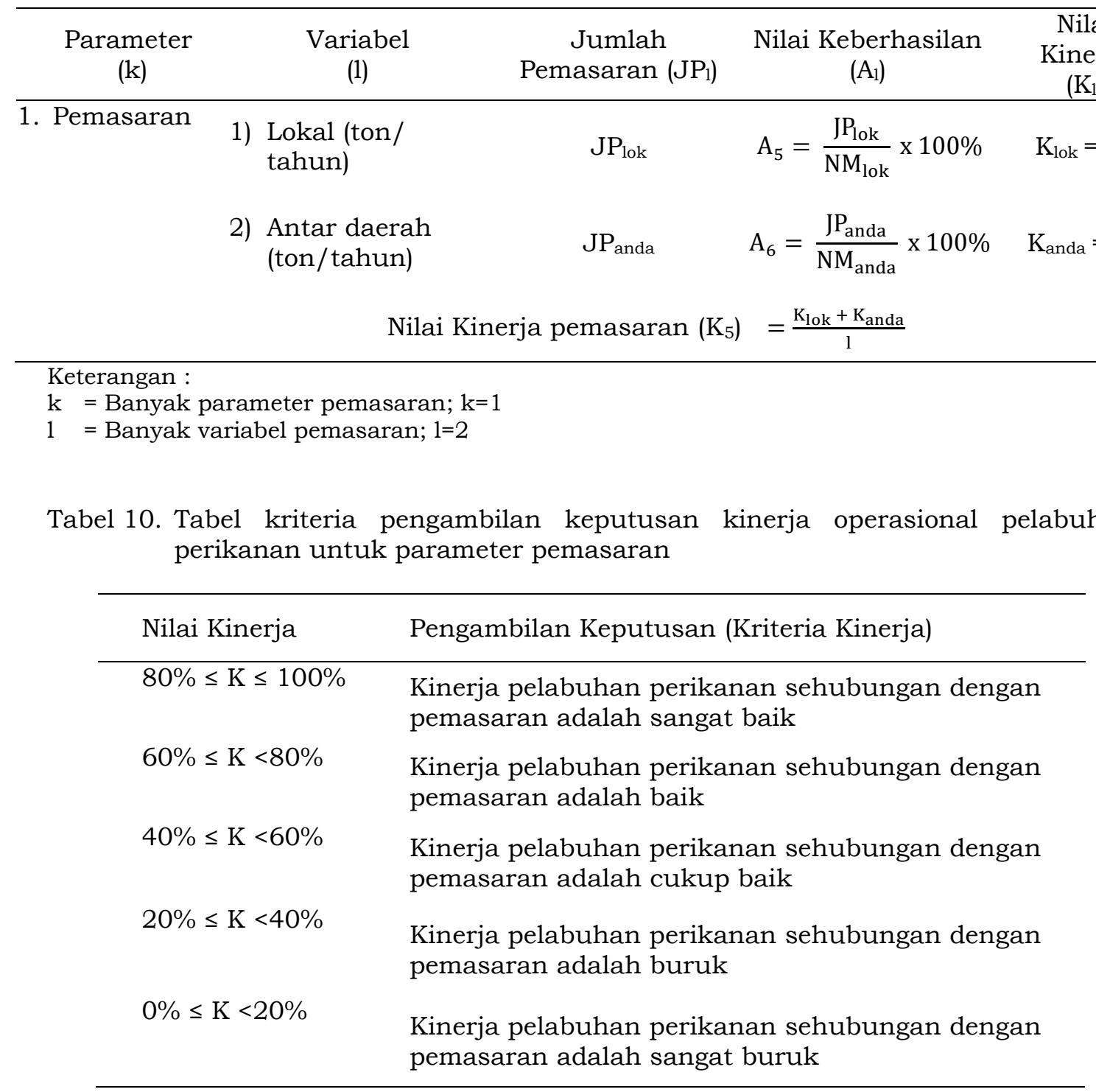

Setelah Skor Maksimum diketahui, maka Nilai Bobot Skor Maksimum juga harus diketahui. Nilai Bobot Skor Maksimum diperoleh dari hasil perkalian antara Bobot Variabel dengan Skor Maksimum (Tabel 12). Nilai Bobot Skor Maksimum tersebut digunakan untuk menentukan Nilai Keberhasilan variabelvariabelnya. Selanjutnya Nilai Keberhasilan diperoleh dari perbandingan antara hasil jawaban responden yang merupakan rata-rata pendapat responden terhadap Nilai Bobot Skor Mak- simum. Nilai Keberhasilan tersebut kemudian cari rata-rata dan diperoleh Nilai Kinerja kepuasan nelayan atau dinotasikan dengan $K_{6}$. Perhitungan Nilai Kinerja parameter kepuasan nelayan dapat dilihat pada Tabel 13. Pengambilan keputusan kinerja pelabuhan perikanan sehubungan dengan parameter kepuasan nelayan dilakukan dengan membandingkan nilai $\mathrm{K}_{6}$ terhadap kriteria pengambilan keputusan kepuasan nelayan (Tabel 14). 
Tabel 11. Tabel skala kriteria untuk tingkat kepuasan responden nelayan tentang ketersediaan fasilitas PPN TUAL

\begin{tabular}{lcl}
\hline $\begin{array}{c}\text { Pendapat responden } \\
\text { (Tingkat Kepuasan) }\end{array}$ & $\begin{array}{c}\text { Skor } \\
\text { (skala) }\end{array}$ & \multicolumn{1}{c}{ Kriteria } \\
\hline Tidak puas & 1 & $\begin{array}{l}\text { Apabila nelayan berpendapat bahwa } \\
\text { fasilitas yang disediakan pihak PPN TUAL } \\
\text { tidak memenuhi kebutuhan nelayan (tidak } \\
\text { terdapat fasilitas yang dibutuhkan oleh } \\
\text { nelayan) } \\
\text { Apabila nelayan berpendapat bahwa } \\
\text { fasilitas yang disediakan pihak PPN TUAL } \\
\text { kurang memenuhi kebutuhan nelayan } \\
\text { Apabila nelayan berpendapat bahwa } \\
\text { fasilitas yang disediakan pihak PPN TUAL } \\
\text { cukup memenuhi kebutuhan nelayan } \\
\text { Apabila nelayan berpendapat bahwa } \\
\text { fasilitas yang disediakan pihak PPN TUAL } \\
\text { telah memenuhi kebutuhan nelayan } \\
\text { Apabila nelayan berpendapat bahwa } \\
\text { fasilitas yang disediakan pihak PPN TUAL } \\
\text { sangat memenuhi kebutuhan nelayan }\end{array}$ \\
Sangat puas & 2 & 5
\end{tabular}

Tabel 12. Tabel perhitungan Nilai Bobot Skor Maksimum untuk parameter kepuasan nelayan

\begin{tabular}{|c|c|c|c|c|c|}
\hline $\begin{array}{l}\text { Parameter } \\
\qquad(\mathrm{m})\end{array}$ & & Variabel (n) & $\begin{array}{c}\text { Bobot } \\
\text { Variabel }\left(\mathrm{BV}_{\mathrm{n}}\right)\end{array}$ & $\begin{array}{l}\text { Skor maksimum } \\
\left(\mathrm{SM}_{\mathrm{n}}\right)\end{array}$ & $\begin{array}{l}\text { Nilai Bobot Skor } \\
\text { Maksimum (NM) } \\
\left(\mathrm{BV}_{\mathrm{n}} \times \mathrm{SM}_{\mathrm{n}}\right)\end{array}$ \\
\hline \multirow[t]{4}{*}{$\begin{array}{l}\text { 1. Kepuasan } \\
\text { nelayan }\end{array}$} & 1) & $\begin{array}{l}\text { Kepuasan } \\
\text { nelayan } \\
\text { terhadap fasilitas } \\
\text { perbekalan }\end{array}$ & 30 & 5 & $\begin{aligned} \mathrm{NM}_{\text {bek }} & =\mathrm{BV}_{\text {bek }} \times \mathrm{SM}_{\text {bek }} \\
& =150\end{aligned}$ \\
\hline & 2) & $\begin{array}{l}\text { Kepuasan } \\
\text { nelayan } \\
\text { terhadap fasilitas } \\
\text { perbaikan }\end{array}$ & 15 & 5 & $\begin{aligned} \mathrm{NM}_{\text {baik }} & =\mathrm{BV}_{\text {baik }} \mathrm{x} \\
\mathrm{SM}_{\text {baik }} & =75 \\
& =75\end{aligned}$ \\
\hline & 3) & $\begin{array}{l}\text { Kepuasan } \\
\text { nelayan } \\
\text { terhadap fasilitas } \\
\text { pendaratan dan } \\
\text { pembongkaran }\end{array}$ & 35 & 5 & $\begin{aligned} \mathrm{NM}_{\mathrm{dar}} & =\mathrm{BV}_{\mathrm{dar}} \times \mathrm{SM}_{\mathrm{dar}} \\
& =175\end{aligned}$ \\
\hline & 4) & $\begin{array}{l}\text { Kepuasan } \\
\text { nelayan } \\
\text { terhadap fasilitas } \\
\text { pemasaran }\end{array}$ & 20 & 5 & $\begin{aligned} \mathrm{NM}_{\text {pas }}= & \mathrm{BV}_{\text {pas }} \times \mathrm{SM}_{\mathrm{pas}} \\
& =100\end{aligned}$ \\
\hline
\end{tabular}


Tabel 13. tabel perhitungan Nilai Kinerja untuk parameter kepuasan nelayan

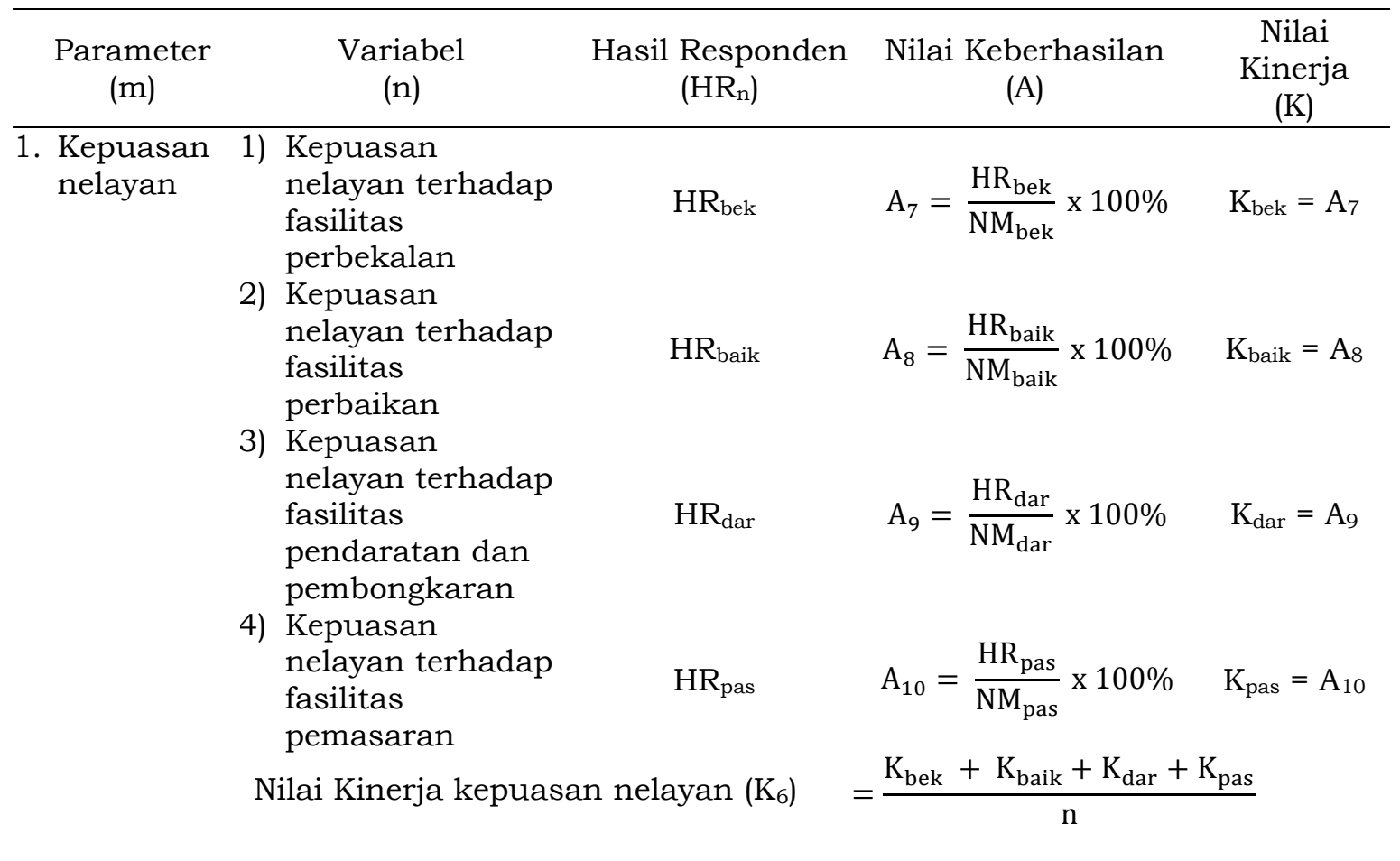

Tabel 14. Tabel kriteria pengambilan keputusan kinerja operasional pelabuhan perikanan untuk parameter kepuasan nelayan

\begin{tabular}{ll}
\hline Nilai Kinerja & Pengambilan Keputusan (Kriteria Kinerja) \\
\hline $80 \% \leq \mathrm{K} \leq 100 \%$ & $\begin{array}{l}\text { Kinerja pelabuhan perikanan sehubungan } \\
\text { dengan kepuasan nelayan adalah sangat baik }\end{array}$ \\
$60 \% \leq \mathrm{K}<80 \%$ & $\begin{array}{l}\text { Kinerja pelabuhan perikanan sehubungan } \\
\text { dengan kepuasan nelayan adalah baik }\end{array}$ \\
$40 \% \leq \mathrm{K}<60 \%$ & $\begin{array}{l}\text { Kinerja pelabuhan perikanan sehubungan } \\
\text { dengan kepuasan nelayan adalah cukup baik }\end{array}$ \\
$20 \% \leq \mathrm{K}<40 \%$ & $\begin{array}{l}\text { Kinerja pelabuhan perikanan sehubungan } \\
\text { dengan kepuasan nelayan adalah buruk }\end{array}$ \\
& $\begin{array}{l}\text { Kinerja pelabuhan perikanan sehubungan } \\
\text { dengan kepuasan nelayan adalah sangat } \\
\text { buruk }\end{array}$ \\
\hline
\end{tabular}

Nilai Kinerja pelabuhan perikanan yang diperoleh dari parameter pemasaran dan kepuasan nelayan tersebut kemudian dicari rata-rata dan dinamakan sebagai Nilai Kinerja parameter nonDJPT atau dinotasikan dengan $\mathrm{K}_{\text {non-DJPT. }}$. Nilai $K_{\text {DJPT }}$ dan nilai $K_{\text {non-DJPT }}$ dirataratakan, sehingga diperoleh Nilai Kinerja operasional PPN Tual atau dengan notasinya $\mathrm{K}_{\mathrm{PPN}-\mathrm{Tual}}$. Setelah nilai $\mathrm{K}_{\mathrm{PPN} \text {-Tual }}$ diperoleh selanjutnya dilakukan pengambilan keputusan gabungan mengenai kriteria kinerja operasional PPN Tual berdasarkan kriteria pengambilan keputusan di Tabel 2. 


\section{HASIL DAN PEMBAHASAN}

Penilaian kinerja operasional PPN Tual diawali dengan mengetahui tujuan pembangunan pelabuhan perikanan dari data sekunder yang diperoleh. Pada hakekatnya tujuan pembangunan PPN Tual ditujukan untuk meningkatkan kesejahteraan masyarakat perikanan terutama para nelayan, sekaligus menjaga kelestarian sumberdaya ikan dan lingkungannya. Oleh karena itu sistem perencanaan pembangunannya harus dilakukan secara komprehensif serta mengarah kepada perwujudan transparansi dan partisipasi masyarakat yang terlibat di dalamnya. Evaluasi kinerja operasional PPN Tual diawali dengan tahap pencarian informasi mengenai tujuan khusus pembangunan PPN Tual. Tujuan khusus dari pembangunan PPN Tual adalah (1) meningkatkan pembangunan sarana dan prasarana pelabuhan dengan kualitas dan kapasitas yang memadai; (2) meningkatkan operasional pelabuhan; (3) meningkatkan pelayanan prima bagi masyarakat pengguna jasa pelabuhan; (4) mewujudkan fungsi pelabuhan perikanan sebagai tempat pelayanan tambat, bongkar muat, pembinaan mutu, pengumpulan data, pelaksanaan penyuluhan, publikasi hasil riset dan pengendalian lingkungan; (5) meningkatkan sistem pengelolaan, pengendalian dan pengawasan sumberdaya ikan; (6) pelabuhan perikanan sebagai sentra produksi hasil perikanan yang bermutu.
Pada perhitungan nilai kinerja dalam penelitian ini dibagi menjadi dua kategori yaitu parameter DJPT dan parameter non-DJPT.

\section{Parameter DJPT}

Pada parameter DJPT perhitungan Nilai Kinerja menggunakan nilai realisasi operasional di PPN Tual tahun 2012 (Tabel 15). Tabel 15 menunjukkan nilai realisasi pencapaian pada tahun 2012 di PPN Tual yang meliputi jumlah produksi hasil tangkapan sebesar 118,03 ton/ tahun, kunjungan kapal 29 unit/tahun, penyediaan perbekalan melaut yang meliputi BBM sebesar 440 ton/tahun dan air bersih sebesar 1.207 ton/tahun. Nilai-nilai tersebut digunakan untuk menentukan Nilai Keberhasilannya. Hasil perhitungan Nilai Keberhasilan dapat dilihat pada Tabel 16. Nilai Keberhasilan yang telah diperoleh, selanjutnya dikalikan dengan bobot untuk masing-masing parameter dan variabel yang telah ditentukan. Hasil perkalian tersebut dinamakan Nilai Kinerja dan dapat dilihat pada Tabel 17, yang menyatakan Nilai Kinerja untuk DJPT adalah sebesar 24,36\%. Nilai ini apabila dimasukkan pada Tabel 2, berada pada selang $20 \% \leq \mathrm{K}<40 \%$. Hal ini berarti bahwa kinerja operasional pelabuhan perikanan untuk DJPT dalam hal ini parameter produksi hasil tangkapan, kunjungan kapal dan penyediaan perbekalan BBM dan air bersih dikatakan buruk.

Tabel 15. Tabel nilai realisasi operasional PPN TUAL tahun 2012

\begin{tabular}{|c|c|c|}
\hline Parameter (i) & Variabel (j) & $\begin{array}{l}\text { Nilai realisasi } \\
(\mathrm{X})\end{array}$ \\
\hline 1. Produksi hasil tangkapan & $\begin{array}{l}\text { 1) Produksi hasil tangkapan per tahun } \\
\text { (ton/tahun) }\end{array}$ & 118,03 \\
\hline 2. Kunjungan kapal & $\begin{array}{l}\text { 1) Frekuensi kunjungan kapal per } \\
\text { tahun (unit kali/tahun) }\end{array}$ & 29 \\
\hline \multirow{2}{*}{$\begin{array}{l}\text { 3. Penyediaan } \\
\text { melaut }\end{array}$} & 1) Penyediaan BBM (ton/tahun) & 440 \\
\hline & $\begin{array}{l}\text { 2) Penyediaan air bersih } \\
\text { (ton/tahun) }\end{array}$ & 1.207 \\
\hline
\end{tabular}

Sumber : PPN TUAL, 2012 
Tabel 16. Hasil perhitungan Nilai Keberhasilan untuk parameter DJPT

Parameter (i) Nariabel (j) Nilai Keberhasilan $\left(\mathrm{A}_{\mathrm{j}}\right.$; \%)

1. Produksi hasil tangkapan

2. Kunjungan kapal

3. Penyediaan perbekalan melaut
1) Produksi hasil tangkapan per tahun (ton/tahun)

1) Frekuensi kunjungan kapal per tahun (unit kali/tahun)

1) Penyediaan BBM (ton/tahun)

2) Penyediaan air bersih (ton/tahun)

$$
\begin{aligned}
\mathrm{A}_{1} & =\frac{118,03}{10.950} \times 100 \% \\
& =1,08 \\
\mathrm{~A}_{2} & =\frac{29}{27.375} \times 100 \% \\
& =0,11 \\
\mathrm{~A}_{3} & =\frac{440}{18.250} \times 100 \% \\
& =2,41 \\
\mathrm{~A}_{4} & =\frac{1.207}{91.250} \times 100 \% \\
& =1,32
\end{aligned}
$$

\begin{tabular}{|c|c|c|c|c|c|c|}
\hline Parameter (i) & & Variabel (j) & $\begin{array}{c}\text { Nilai } \\
\text { Keberhasilan } \\
\left(A_{j}\right)\end{array}$ & $\begin{array}{c}\text { Bobot } \\
\text { Parameter } \\
\left(\mathrm{BP}_{\mathrm{i}}\right)\end{array}$ & $\begin{array}{c}\text { Bobot } \\
\text { Variabel } \\
\left(\mathrm{BV}_{\mathrm{j}}\right)\end{array}$ & $\begin{array}{c}\text { Nilai Kinerja } \\
\left(\mathrm{K}_{\mathrm{j}}=\mathrm{A}_{\mathrm{j}} \mathrm{x} \mathrm{BP}_{\mathrm{i}} \mathrm{x}\right. \\
\left.\mathrm{BV}_{\mathrm{j}}\right)\end{array}$ \\
\hline $\begin{array}{l}\text { 1. Produksi } \\
\text { hasil } \\
\text { tangkapan }\end{array}$ & 1) & $\begin{array}{l}\text { Produksi per } \\
\text { tahun } \\
\text { (ton/tahun) }\end{array}$ & 1,078 & 35 & 100 & $\mathrm{~K}_{1}=37,73$ \\
\hline $\begin{array}{l}\text { 2. Kunjungan } \\
\text { kapal }\end{array}$ & 1) & $\begin{array}{l}\text { Frekuensi } \\
\text { kunjungan kapal } \\
\text { per tahun (unit } \\
\text { kali/tahun) }\end{array}$ & 0,106 & 35 & 100 & $\mathrm{~K}_{2}=3,71$ \\
\hline \multirow{2}{*}{$\begin{array}{l}\text { 3. Penyediaan } \\
\text { perbekalan } \\
\text { melaut }\end{array}$} & 1) & $\begin{array}{l}\text { Penyediaan BBM } \\
\text { (ton/tahun) }\end{array}$ & 2,411 & \multirow{2}{*}{30} & 50 & $\mathrm{~K}_{3}=36,16$ \\
\hline & 2) & $\begin{array}{l}\text { Penyediaan air } \\
\text { bersih (ton/tahun) }\end{array}$ & 1,323 & & 50 & $\mathrm{~K}_{4}=19,84$ \\
\hline \multicolumn{6}{|c|}{ Nilai Kinerja Data DJPT (K $\left.\mathrm{K}_{\mathrm{DJPT}}\right)$} & $=24,36$ \\
\hline
\end{tabular}

Tabel 17. Hasil perhitungan Nilai Kinerja untuk parameter DJPT

\section{Parameter non-DJPT}

Pada parameter non-DJPT, perhitungan Nilai Kinerja untuk parameter pemasaran dan parameter kepuasan nelayan dipisahkan karena cara perhitungannya yang berbeda. Adapun hasil perhitungan Nilai Kinerja untuk parameter pemasaran dan kepuasan nelayan dapat dilihat pada Tabel 18 dan 19 .

Dari Tabel 18 dapat dilihat bahwa Nilai Kinerja untuk parameter pemasaran adalah sebesar 0,24\%. Nilai ini apabila dimasukkan pada Tabel 7, berada pada selang $0 \% \leq \mathrm{K}<20 \%$, yang berarti kinerja operasional pelabuhan perikanan untuk parameter pemasaran dikatakan sangat buruk. Dari Tabel 20 terlihat bahwa Nilai Kinerja untuk parameter kepuasan nelayan adalah sebesar $37,5 \%$. Nilai ini apabila dimasukkan pada Tabel 7 , berada pada selang $20 \% \leq \mathrm{K}<40 \%$, yang berarti bahwa kinerja operasional pelabuhan perikanan untuk parameter kepuasan nelayan dikatakan buruk. 
Tabel 18. Hasil perhitungan Nilai Kinerja untuk parameter pemasaran

\begin{tabular}{|c|c|c|c|c|c|}
\hline Parameter $(\mathrm{m})$ & & Variabel (n) & $\begin{array}{c}\text { Jumlah } \\
\text { Pemasaran }\left(\mathrm{JP}_{\mathrm{n}}\right)\end{array}$ & $\begin{array}{l}\text { Nilai Keberhasilan } \\
\left(\mathrm{A}_{\mathrm{n}} ; \%\right)\end{array}$ & $\begin{array}{c}\text { Nilai Kinerja } \\
\left(\mathrm{K}_{\mathrm{n}}\right)\end{array}$ \\
\hline \multirow{2}{*}{ 1. Pemasaran } & 1) & Lokal & 0 & $\begin{aligned} A_{5} & =\frac{0}{52.532} \times 100 \% \\
& =0\end{aligned}$ & $\mathrm{~K}_{\mathrm{lok}}=0$ \\
\hline & 2) & Antar daerah & $7.081,56$ & $\begin{aligned} \mathrm{A}_{6}= & \frac{7 \cdot 081,56}{1.497 \cdot 162} \times 100 \% \\
& =0,473\end{aligned}$ & $\mathrm{~K}_{\mathrm{anda}}=0,47$ \\
\hline & & & & Nilai Kinerja pemasara & $\left(K_{6}\right)=0,24$ \\
\hline
\end{tabular}

Tabel 19. Hasil perhitungan Nilai Kinerja untuk parameter kepuasan nelayan

\begin{tabular}{|c|c|c|c|c|c|}
\hline Parameter $(\mathrm{m})$ & & Variabel (n) & $\begin{array}{c}\text { Hasil } \\
\text { Responden } \\
\left(\mathrm{HR}_{\mathrm{n}}\right)\end{array}$ & $\begin{array}{l}\text { Nilai Keberhasilan } \\
\left(\mathrm{A}_{\mathrm{n}} ; \%\right)\end{array}$ & $\begin{array}{c}\text { Nilai Kinerja } \\
\left(\mathrm{K}_{\mathrm{n}}\right)\end{array}$ \\
\hline \multirow{5}{*}{$\begin{array}{l}\text { 1. Kepuasan } \\
\text { nelayan }\end{array}$} & 1) & $\begin{array}{l}\text { Kepuasan } \\
\text { nelayan } \\
\text { terhadap fasilitas } \\
\text { perbekalan }\end{array}$ & 75 & $\begin{aligned} A_{7}= & \frac{75}{150} \times 100 \% \\
& =50\end{aligned}$ & $\mathrm{~K}_{\mathrm{bek}}=50$ \\
\hline & 2) & $\begin{array}{l}\text { Kepuasan } \\
\text { nelayan terhadap } \\
\text { fasilitas } \\
\text { perbaikan }\end{array}$ & 15 & $\begin{aligned} A_{8} & =\frac{15}{75} \times 100 \% \\
& =20\end{aligned}$ & $\mathrm{~K}_{\text {baik }}=20$ \\
\hline & 3) & $\begin{array}{l}\text { Kepuasan } \\
\text { nelayan terhadap } \\
\text { fasilitas } \\
\text { pendaratan dan } \\
\text { pembongkaran }\end{array}$ & 105 & $\begin{aligned} A_{9} & =\frac{105}{175} \times 100 \% \\
& =60\end{aligned}$ & $\mathrm{~K}_{\mathrm{dar}}=60$ \\
\hline & 4) & $\begin{array}{l}\text { Kepuasan } \\
\text { nelayan terhadap } \\
\text { fasilitas } \\
\text { pemasaran }\end{array}$ & 20 & $\begin{aligned} A_{10} & =\frac{20}{100} \times 100 \% \\
& =20\end{aligned}$ & $\mathrm{~K}_{\mathrm{pas}}=20$ \\
\hline & & & \multicolumn{3}{|c|}{ Nilai Kinerja kepuasan nelayan $\left(\mathrm{K}_{6}\right)=37,5$} \\
\hline
\end{tabular}

Nilai Kinerja dari parameter pemasaran dan kepuasan nelayan yang diperoleh kemudian dirata-ratakan. Adapun nilai yang diperoleh adalah $18,87 \%$ dan disebut sebagai Nilai Kinerja non-DJPT atau dinotasikan dengan $\mathrm{K}_{\text {non-DJPT. }}$ Nilai $\mathrm{K}_{\text {non-DJPT }}$ dan $\mathrm{K}_{\mathrm{DJPT}}$ dirata-ratakan lagi sehingga diperoleh nilai $21,61 \%$ selanjutnya disebut Nilai Kinerja operasional PPN Tual atau dengan notasinya $K_{\text {PPN Tual }}$. Berdasarkan kriteria pengambilan keputusan pada Tabel 16, maka Nilai Kinerja operasional dari PPN Tual ini berada pada $20 \% \leq \mathrm{K}<40 \%$ dan dikatakan buruk. Penilaian kinerja ini sejalan dengan hasil penelitian Nikijuluw et al (2005), yang menyatakan bahwa pelayanan PPN Tual belum dapat dilaksanakan secara optimal, disebabkan karena masih banyak kekurangan fasilitas seperti ukuran panjang dermaga masih belum memadai, belum adanya sarana pelayanan seperti galangan kapal, cold storage/cool room, rusaknya fasilitas tangki air bersih dan BBM, kurangnya pendukung perkantoran berupa meubel air, demikian juga dengan kinerja sumberdaya manusia yang sangat terbatas dan belum memahami tugas kepelabuhanan.

\subsection{Parameter Produksi}

Pada Tabel 16 dapat dilihat bahwa Nilai Keberhasilan untuk parameter produksi adalah $1,08 \%$. Nilai ini menunjukkan bahwa produksi ikan di PPN Tual jumlahnya sangat sedikit yaitu hanya 118,03 ton/tahun. Jumlah ini sangat 
jauh dibawah standar indikator jumlah produksi perikanan untuk ukuran PPN berdasarkan Keputusan Direktur Jenderal Perikanan Tangkap Nomor: 432/ DPT3/OT.220.D3/I/2008 yaitu sebesar 10.950 ton/tahun. Berdasarkan nilai yang diperoleh dapat dikatakan bahwa pendaratan ikan di PPN Tual sangat kurang bagus. Kondisi ini dipengaruhi oleh jumlah kunjungan kapal di PPN Tual yang mengalami penurunan drastis dan bahkan dalam tahun 2012 hanya terjadi 29 kali kunjungan kapal. Dengan demikian apabila frekuensi jumlah kunjungan kapal di pelabuhan perikanan sedikit maka akan mempengaruhi produksi ikan yang didaratkan juga mengalami jumlah yang sedikit.

Pihak pengelola PPN Tual dalam laporan tahunan 2012 selain mencatat jumlah hasil tangkapan yang didaratkan di PPN Tual, juga mencatat jumlah hasil tangkapan yang didaratkan di dermaga sekitar yaitu dermaga bongkar milik PT. Maritim Timur Jaya dan PT. Pusaka Benjina Resources. Hal ini dilakukan untuk memenuhi salah satu fungsinya yaitu melakukan pengumpulan data tangkapan dan hasil perikanan agar mendukung pelaksanaan pengawasan dan pengendalian sumberdaya perikanan.

Menurut Lubis (2012), keberadaan hasil tangkapan yang didaratkan di suatu pelabuhan perikanan akan menentukan tingkat operasional dari fasilitas yang telah dibangun karena hasil tangkapan merupakan salah satu indikator tingkat fungsionalisasi suatu pelabuhan perikanan. Pelabuhan perikanan merupakan mata rantai terpenting yang menghubungkan kegiatan penangkapan ikan dengan distribusi komoditi ikan ke konsumen. Produksi ikan yang merupakan hasil kegiatan usaha penangkapan sebagai barang produksi akan sampai ke konsumen sebagai bahan pangan dan sangat dipengaruhi oleh keadaan sarana dan prasarana pelabuhan. Oleh karena itu untuk lebih meningkatkan kinerja operasional PPN Tual, maka pihak PPN Tual harus lebih meningkatkan produksi hasil tangkapan yang didaratkan di PPN Tual salah satunya dengan melakukan pemeliharaan dan pengembangan fasilitas di PPN Tual. Hal ini sejalan dengan penelitian Suherman (2011), dinyatakan bahwa untuk memperlancar aktivitas perikanan tangkap khususnya usaha penangkapan ikan di PPN Pengambengan maka perlu dilakukan pemeliharaan dan pengembangan fasilitas operasional pelabuhan perikanan.

\subsection{Parameter kunjungan kapal}

Pada Lampiran 16 dapat dilihat bahwa Nilai Keberhasilan untuk parameter kunjungan kapal hanya 0,106\%. Nilai tersebut diperoleh karena jumlah kunjungan kapal di PPN Tual dalam tahun 2012 hanya sebanyak 29 kali, yang berarti bahwa jumlah tersebut sangat kecil jika dibandingkan dengan standar indikator yang digunakan untuk ukuran frekuensi kunjungan kapal di PPN berdasarkan Keputusan Direktur Jenderal Perikanan Tangkap Nomor: 432/DPT3/OT.220.D3/I/2008 yaitu 27.375 unit kali/tahun. Ukuran kapal yang melakukan kunjungan ke PPN Tual berukuran 100-200 GT. Kapal-kapal tersebut merupakan kapal-kapal industri penangkapan ikan yang semua hasil tangkapannya ditujukan untuk ekspor sehingga lama tripnya mencapai berbulan-bulan dan mengakibatkan jarang melakukan kunjungan ke PPN Tual. Selain itu rendahnya jumlah kunjungan kapal juga terjadi sebagai imbas dari penertiban pihak yang berwajib akibat illegal fishing pada tahun 2007 sehingga menimbulkan ketakutan bagi beberapa perusahaan yang berpangkalan di PPN Tual sehingga mereka akhirnya keluar dari PPN Tual. Saat pengamatan dilakukan, sudah ada upaya yang dilakukan pihak PPN Tual agar dapat mengembalikan kepercayaan para pengusaha perikanan agar dapat kembali berinvestasi di PPN Tual, melakukan kunjungan kapal dan mendaratkan hasil tangkapannya. Parameter kunjungan kapal dianggap sebagai salah satu parameter yang perlu mendapatkan perhatian khusus sehingga perlu terus ditingkatkan lagi, agar penilaian kinerja operasional PPN Tual menjadi lebih tinggi.

\subsection{Parameter penyediaan perbekalan melaut}

Parameter penyediaan perbekalan melaut di PPN Tual meliputi dua variabel yaitu BBM dan air bersih. Kedua variabel ini memiliki Nilai Keberhasilan yang berbeda-beda yaitu untuk BBM 2,41\% dan untuk air bersih 1,32\%. Nilai ini menunjukkan bahwa penyediaan perbekalan BBM di PPN Tual yang hanya 
berjumlah 440 ton per tahun belum mencapai jumlah penyediaan perbekalan BBM untuk PPN berdasarkan Keputusan Direktur Jenderal Perikanan Tangkap Nomor: 432/DPT3/OT.220.D3/I/2008 yaitu sebesar 18.250 ton per tahun. Sama halnya dengan penyaluran BBM, penyaluran air bersih yang hanya berjumlah 1.207 ton per tahun juga belum mencapai jumlah perbekalan melaut untuk PPN berdasarkan Keputusan Direktur Jenderal Perikanan Tangkap Nomor: 432/DPT3/OT.220.D3/I/2008 yaitu sebesar 91.250 ton per tahun. Rendahnya jumlah penyaluran BBM dan air bersih di PPN Tual ini disebabkan karena jumlah kunjungan kapal yang terjadi di PPN Tual juga rendah sehingga jumlah permintaan perbekalan BBM dan air bersih juga hanya sedikit. Penyaluran kebutuhan melaut BBM di PPN Tual dipasok dari pertamina setempat. Hal ini dikarenakan tangki BBM yang ada di PPN Tual yang telah disewakan kepada PT. Getra Mitra Usaha belum digunakan sebagaimana mestinya. Penyaluran kebutuhan air bersih dipasok dari luar PPN Tual menggunakan mobil tangki karena pipa penyalur air bersih dalam kondisi rusak dan mengalami kebocoran. Penurunan jumlah permintaan perbekalan BBM di PPN Tual ini sama halnya juga terjadi di PPN Pekalongan seperti pada penelitian Nasir et al (2012) yang menyatakan bahwa turunnya jumlah penyaluran solar di PPN Pekalongan dikarenakan turunnya jumlah kapal yang beroperasi ke laut.

\subsection{Parameter pemasaran}

Parameter pemasaran terdiri dari dua variabel yaitu pemasaran lokal dengan Nilai Keberhasilannya $0 \%$ dan pemasaran antar daerah dengan Nilai Keberhasilannya 0,47\%. Nilai ini menunjukkan bahwa jumlah pemasaran di PPN Tual masih jauh di bawah Skor Maksimum pemasaran lokal dan antar daerah untuk PPN. Adapun skor maksimum yang digunakan adalah jumlah pemasaran hasil tangkapan Pelabuhan Perikanan Nusantara (PPN) Brondong tahun 2012; dengan asumsi jumlah pemasaran hasil tangkapan PPN Brondong merupakan jumlah pemasaran terbaik di Indonesia untuk kelas Pelabuhan Perikanan Nusantara.

Hasil yang diperoleh pada penelitian ini berbeda dengan yang dican- tumkan oleh pihak PPN Tual pada Laporan Tahunan 2012 yaitu bahwa di PPN Tual ada pemasaran untuk luar negeri. Hal ini dapat dijelaskan bahwa untuk data ekspor yang disajikan dalam laporan tahunan tersebut diperoleh dari pemberitahuan ekspor barang yang telah disetujui oleh Direktorat Bea dan Cukai Tual. Data ekspor tersebut hampir sebagian besar bukan hasil tangkapan yang didaratkan di PPN Tual melainkan dari dermaga-dermaga milik swasta yang berada di dekat PPN Tual seperti PT. Maritim Timur Jaya dan PT. Pusaka Bahari Resources. Hal ini dikarenakan jumlah produksi yang didaratkan di PPN Tual jumlahnya sedikit. Ekspor hasil perikanan dari Tual dilakukan ke negara China dalam bentuk utuh beku (frozen) tanpa ada proses pengolahan. Selain ekspor langsung ke luar negeri, beberapa perusahaan perikanan maupun perorangan juga melakukan pengiriman ikan hidup ke Ambon dan Bali sedangkan ikan utuh beku (frozen) ke Jakarta. Ikan beku yang dikirim ke luar daerah tersebut dimuat di PPN Tual oleh beberapa perusahaan dan perorangan, sedangkan ikan hidup dimuat di lokasi penangkapan ikan (keramba) yang tersebar di wilayah Kota Tual dan Kabupaten Maluku Tenggara.

\subsection{Parameter kepuasan nelayan}

Parameter kepuasan nelayan merupakan hasil dari wawancara dengan nelayan. Nelayan ditanya mengenai kepuasan terhadap penyediaan fasilitas dan kualitas pelayanan yang diberikan PPN Tual. Nelayan yang menyatakan cukup puas, puas dan sangat puas terhadap pelayanan yang diberikan pihak PPN Tual akan menjadi penentu besarnya nilai keberhasilan pada parameter dan variabel dari kepuasan nelayan. Variabel yang digunakan adalah penyediaan dan pelayanan fasilitas perbekalan, penyediaan dan pelayanan fasilitas pemeliharaan dan perbaikan, penyediaan dan pelayanan fasilitas pendaratan dan pembongkaran, penyediaan dan pelayanan fasilitas pemasaran. Dari hasil perhitungan diperoleh nilai kinerja dari parameter kepuasan nelayan adalah $37,5 \%$.

Variabel yang pertama adalah penyediaan dan pelayanan fasilitas perbekalan. Sebelum melaut para nelayan memastikan adanya perbekalan solar 
dan air bersih. Perbekalan di PPN Tual sampai saat pengamatan dilakukan berasal dari luar pelabuhan baik itu pelayanan air bersih maupun BBM. Hal ini terjadi karena kontrak perjanjian antara PPN Tual dengan pihak ketiga untuk penyediaan perbekalan belum ditaati oleh pihak ketiga sehingga pelayanan perbekalan yang seharusnya berasal dari PPN Tual sendiri menjadi terbengkalai. Sebanyak 58,75\% responden nelayan menyatakan kurang puas dengan fasilitas penyediaan dan pelayanan perbekalan karena pasokan perbekalan berasal dari luar pelabuhan sehingga harga yang diperoleh juga menjadi mahal. Sisanya yaitu 41,25\% menyatakan cukup puas karena walaupun harganya agak mahal namun perbekalan masih bisa dilakukan oleh PPN Tual dan tidak harus mencari sendiri ke luar pelabuhan. Dengan demikian berdasarkan perhitungan yang dilakukan dapat diketahui bahwa Nilai Keberhasilan untuk variabel penyediaan dan pelayanan fasilitas perbekalan di PPN Tual adalah 50\%.

Variabel yang kedua adalah penyediaan dan pelayanan fasilitas pemeliharaan dan perbaikan yang digunakan untuk memperbaiki kapal dan alat tangkap. Fasilitas pemeliharaan dan perbaikan yang disediakan oleh pihak PPN Tual adalah bengkel dan tempat perbaikan jaring. Dari hasil wawancara yang diperoleh, 100\% nelayan menyatakan tidak puas dan berdasarkan perhitungan yang dilakukan dapat diketahui bahwa Nilai Keberhasilannya adalah 20\%. Menurut para nelayan bahwa mereka tidak pernah menggunakan fasilitas tersebut. Fasilitas bengkel ada di PPN Tual namun tidak dipergunakan sebagaimana mestinya. Tempat perbaikan jaring di PPN Tual berupa gedung dengan jenis konstruksinya setengah beton. Kondisi gedung baik namun belum dimanfaatkan sesuai fungsinya disebabkan letaknya pada dataran yang lebih tinggi sehingga sulit dilakukan penarikan jaring ke tempat tersebut. Gedung perbaikan jaring ini telah dialih fungsikan untuk pembangunan pabrik es oleh PT. Pusaka Bahari setelah mendapat persetujuan dari Direktur Jenderal Perikanan Tangkap namun hingga saat pengamatan dilakukan, pembangunan belum dilaksanakan.
Variabel yang ketiga adalah penyediaan dan pelayanan fasilitas pendaratan dan pembongkaran yang terdiri dari dermaga dan kolam pelabuhan. Dermaga merupakan fasilitas tambat labuh dimana terdapat kegiatan bongkar ikan, pengisian perbekalan bahkan perbaikan. Penilaian kepuasan nelayan terhadap pelayanan fasilitas pendaratan dan pembongkaran perlu dilakukan untuk mengetahui kinerja penyediaan dan pelayanan fasilitas pendaratan dan pembongkaran. Sebanyak $51,20 \%$ responden nelayan menyatakan kurang puas dengan fasilitas penyediaan dan pelayanan fasilitas pendaratan dan pembongkaran. Nelayan yang menyatakan kurang puas ini ratarata merupakan nelayan lokal yang belum pernah melakukan pendaratan di PPN Tual karena dermaga yang tersedia adalah untuk kapal-kapal di atas 30 GT, tidak dapat disinggahi oleh kapal-kapal ikan mereka yang berukuran kurang dari 30 GT. Selain itu beberapa orang dari mereka mengatakan sampai saat ini belum pernah mengetahui bahwa PPN Tual merupakan pelabuhan perikanan karena kurangnya sosialisasi dari pihak pengelola mengenai fungsi dari PPN Tual itu sendiri. Sisa dari presentase responden yaitu 48,75\% menyatakan cukup puas karena mereka masih bisa memanfaatkan dermaga untuk berlabuh/bertambat guna mengisi perbekalan melaut. Selain itu dukungan cukup puas mereka karena kolam pelabuhan di PPN Tual memiliki kedalaman pada saat surut terendah adalah 8 meter dan pasang tertinggi adalah 14 meter. Tinggi antara lantai dasar dermaga dengan permukaan surut terendah adalah 3 meter. Kolam pelabuhan di PPN Tual secara fisik sudah cukup luas sehingga dapat menampung semua kapal yang datang berlabuh, serta dapat bergerak bebas. Dalam hal penyediaan dan pelayanan terhadap fasilitas pendratan dan pembongkaran, pihak PPN Tual sudah menyediakan dermaga dan kolam pelabuhan. Berdasarkan rata-rata pendapat responden yang diwawancarai dapat diketahui bahwa Nilai Keberhasilan dari subparameter penyediaan dan pelayanan fasilitas pendaratan dan pembongkaran adalah $60 \%$.

Variabel yang keempat adalah penyediaan dan pelayanan fasilitas pemasaran yaitu TPI dan pasar ikan, namun di PPN Tual hanya tersedia TPI. Gedung TPI belum berfungsi seba- 
gaimana mestinya sehingga setelah mendapat persetujuan dari Direktur Jenderal Perikanan Tangkap maka saat ini telah dialih fungsikan untuk pembangunan cold storage oleh PT. Pusaka Bahari, namun sampai saat pengamatan dilakukan, pembangunan cold storage belum dilaksanakan. Selain TPI fasilitas pemasaran lainnya adalah pasar ikan. Fasilitas pasar ikan merupakan tempat masyarakat umum membeli ikan langsung ke pedagang di pelabuhan perikanan. Fasilitas pasar ikan belum ada di dalam kompleks PPN Tual, sehingga apabila ada hasil tangkapan yang ingin dipasarkan, maka nelayan akan membawanya ke pasar ikan yang berada di luar komplek PPN Tual. Pasar ikan tersebut berjumlah 2 unit dengan jarak 3 $\mathrm{km}$ dan $45 \mathrm{~km}$ dari PPN Tual. Berdasarkan hasil wawancara yang diperoleh maka semua nelayan menyatakan $100 \%$ tidak puas dengan Nilai Keberhasilannya adalah $20 \%$.

Menurut Guswanto et al (2012) terciptanya suatu pelayanan yang baik di suatu pelabuhan perikanan merupakan suatu hal yang mutlak dan harus diusahakan, karena pelayanan merupakan salah satu kegiatan yang menentukan keberhasilan pengembangan dan pembangunan pelabuhan perikanan. Salah satu faktor yang menentukan kepuasan nelayan adalah persepsi nelayan mengenai atribut pelayanan. Persepsi tersebut menjadi harapan mereka terhadap pelayanan yang disediakan oleh pihak pelabuhan perikanan. Perlu diketahui juga bahwa untuk lebih meningkatkan kinerja PPN TUAL maka tidak cukup hanya melihat produksi, kunjungan kapal, penyediaan perbekalan melaut, pemasaran dan kepuasan nelayan saja tetapi perlu performa lainnya yaitu Kekuatan Hasil Tangkapan (KHT). Menurut Pane (2008) diacu dalam Pane (2010), bahwa KHT suatu tempat pendaratan ikan atau pelabuhan perikanan adalah kemampuan keunggulan hasil tangkapan yang ada di suatu tempat pendaratan ikan atau pelabuhan perikanan tersebut. Komponen-komponen dalam KHT di suatu pelabuhan perikanan meliputi yaitu jenis-jenis ikan yang tersedia, volume atau ketersediaan jumlah ikan, mutu ikan, ukuran ikan yang tersedia dan harga ikan. Kekuatan hasil tangkapan ini sangat penting tidak hanya bagi nelayan sebagai penjual ikan, namun juga sebagai pedagang ikan, pengolah ikan, pengelola pelabuhan dan pemerintah.

\section{KESIMPULAN}

Nilai Kinerja operasional Pelabuhan Perikanan Nusantara Tual (PPN Tual) yang didapat dari hasil perhitungan adalah $21,61 \%$. Berdasarkan selang yang dibuat maka nilai tersebut berada pada selang $20 \% \leq \mathrm{K}<40 \%$ dan dapat dikatakan bahwa kinerja operasional PPN Tual adalah buruk. Pengelola PPN Tual harus berusaha sebaik mungkin untuk meningkatkan produksi hasil tangkapan, jumlah kunjungan kapal, penyediaan perbekalan melaut, pelayanan prima kepada pengguna jasa dan kekuatan hasil tangkapan yang dilakukan dengan menerapkan strategi-strategi peningkatan kinerja operasional PPN Tual.

\section{DAFTAR PUSTAKA}

[DKP] Departemen Kelautan dan Perikanan. 2008. Keputusan Direktur Jenderal Perikanan Tangkap No. 432/DPT3/OT.220.D3/I/2008 tentang Pedoman Evaluasi Kinerja Unit Pelaksana Teknis Pelabuhan Perikanan. Jakarta (ID): DKP.

Guswanto B, Gumilar I, dan Hamdani H. 2012. Analisis Indeks Kinerja Pengelola dan Indeks Kepuasan Pengguna di Pelabuhan Perikanan Samudera Nizam Zachman Jakarta. Jurnal Perikanan dan Kelautan. 3(4): 151-163.

[KKP] Kementerian Kelautan dan Perikanan. 2011. Keputusan Menteri Kelautan dan Perikanan Republik Indonesia Nomor 45 Tahun 2011 tentang Estimasi Potensi Sumber Daya Ikan di Wilayah Pengelolaan Perikanan Negra Republik Indonesia. Jakarta (ID): KKP.

Lubis E. 2012. Pelabuhan Perikanan. Bogor (ID): IPB Press.

Nasir H, Rosyid A, Wijayanto D. 2012. Analisis Kinerja Pengelola Pelabuhan Perikanan Nusantara Pekalongan Jawa Tengah. Journal of Fisheries Resources Utilization Management and Technology. 1(1): 32-45.

Nikijuluw VPH, Huliselan NV, Lesnussa 
FP, dan Matakupan H. 2005. Analisis Sebaran Temporal Penangkapan Ikan sebagai Basis Kebijakan Pengembangan Pelabuhan Perikanan Nusantara (PPN) Tual. Ichthyos. 4(2): 45-54.

Pane, AB. 2008. Persaingan Hasil Tangkapan antar Tempat Pendarat-an. Modul Perkuliahan Analisis Hasil Tangkapan. Bagian Kepelabuhanan Perikanan dan Kebijakan Pengelolaan Departemen Pemanfaatan Sumberdaya Perikanan, FPIK IPB. Bogor (ID): Institut Pertanian Bogor.

[PPN TUAL] Pelabuhan Perikanan Nusantara Tual. 2013. Laporan Tahunan 2012. Tual (ID): PPN TUAL.

Suherman A. 2011. Formulasi Strategi Pengembangan Pelabuhan Perikanan Nusantara Pengambengan Jem-brana. Jurnal Marine Fisheries. 2(1): 87-99. 